\title{
Antibiotic resistance pattern of bacteria isolated from pipe-borne chlorinated (Treated) water and untreated water in ilorin
}

\begin{abstract}
The antibiotic resistance pattern of bacteria isolated from chlorinated (treated) and untreated water was assessed with a view to ascertain the effectiveness of the quality of water employed in the city. Water samples were collected from taps, bore-hole, well and stream. A total of seven (7) bacterial species were isolated from the various samples analysed, the bacteria isolated are Staphylococcus aureus, Enterobacter aerogenes, Escherichia coli, Pseudomonas aeroginos, Bacillus subtilis, Klebsiella pneumonia and Streptococcus faecalis, Heterotrophic plate count (HPC), ranged from $0.5 \times 104 \mathrm{cfu} / \mathrm{ml}$ to $6.6 \times 109 \mathrm{cfu} / \mathrm{ml}$, total enteric bacterial count ranged from $0.3 \times 104 \mathrm{cfu} /$ $\mathrm{ml}$ to $2.1 \times 109 \mathrm{cfu} / \mathrm{ml}$ and total coli form count using the most probable number (MPN) ranged from 0 to $1.8 \times 103 \mathrm{cfu} / 100 \mathrm{ml}$. Untreated water recorded the higher $\mathrm{HPC}$, enteric bacteria count and MPN than treated water. The $\mathrm{pH}$ values ranged from 5.07-7.04, temperature ranged from $20.3^{\circ} \mathrm{C}$ to $24.3^{\circ} \mathrm{C}$, turbidity ranged from $0.251 \mathrm{NTU}$ to 0.846 NTU (Nephelometric Turbidity Unit), free residual chlorine ranged from $0.1 \mathrm{mg} / 1$ to $0.9 \mathrm{mg} / \mathrm{l}$, chloride ion concentration ranged from $2.70 \mathrm{mg} / 1$ to $11.20 \mathrm{mg} / 1$, sulphate ion concentration ranged from $0.87 \mathrm{mg} / 1$ to $5.14 \mathrm{mg} / 1$ and nitrate concentration ranged from $1.04 \mathrm{mg} / 1$ to $1.43 \mathrm{mg} / 1$. Bacillus subtilis, Pseudomonas aeruginosa and Staphylococcus aureus had $75 \%$ occurrence, while Klebsiella pneumonia and Streptococcus faecalis had the least occurrence of $25 \%$. The isolates were resistant to different antibiotics. All the microorganisms isolated were susceptible to ofloxacin and augmentin. This study demonstrates that though chlorine is a bactericide, it does not destroy all bacteria unless it is given under suitable conditions and that bacteria exhibit a high level of resistance to antibiotics.
\end{abstract}

Keywords: antibiotic, resistance, pipe-borne, water, chlorinated, untreated, ilorin
Volume 4 Issue I - 2017

\author{
Orogu JO,' Oyeyiola GP, ${ }^{2}$ Adebisi $\mathrm{OO}^{3}$ \\ 1,2Department of Science Laboratory Technology, Delta State \\ Polytechnic Ozoro, Nigeria \\ ${ }^{3}$ Department of Microbiology, University of llorin (UNILORIN), \\ Nigeria
}

\section{Correspondence: Orogu JO, Department of Science Laboratory Technology, Delta State Polytechnic Ozoro, Delta} State, Nigeria, Email joshuaorogu4@gmail.com

Received: September 08, 2017 | Published: September 29, 2017
Abbreviations: MPN, most probable number; HPC, heterotrophic plate count; NTU, nephelometric turbidity unit; CRD, completely randomized design; DMRT, duncan multiple range test

\section{Introduction}

Water is an important constituent of all forms of life. It helps to sustain life and plays a key role in cell metabolic process. Adam \& Moss ${ }^{1}$ reiterated its importance by stating that "life is totally dependent on the presence of water". It was reported by Harrison ${ }^{2}$ to be the most abundant of all resources, while Brock et al. ${ }^{3}$ reported that it covers about $70 \%$ of the whole earth's surface. Water can be divided into two (2) main sources namely surface and underground water. Surface water is made up of water bodies that are exposed directly to the atmosphere. They include rivers, lakes, and streams and so on. Surface water is easily contaminated by human pathogens through direct and indirect input of municipal sewage and other source of human and animal excreta (Encyclopedia of Microbiology vol. 4). Surface water generally requires treatment to ensure their portability for human consumption. Underground water is made up of water bodies that are not directly exposed to the atmosphere but are submerged within the earth's crust. Examples include wells, springs, and so on. It is generally believed that ground- water is the purest form of naturally occurring water. ${ }^{4}$ This is due to the fact that the passage of water through the soil sediments tends to retain contaminating agents, ${ }^{5}$ However, this assumption is not totally acceptable because ground water is not always free of microorganisms. Pathogenic organisms that may reach the soil and eventually the ground water include bacteria, fungi and so on. As the world remains today, no single day passes without water being put to use by a community or group of individuals. This draws one's attention to how important water is. Water remains the most important and indispensable commodity that supports the existence of life on earth, yet, unevenly distributed throughout the world. Hence, every effect must be put in place to ensure its safety. Water is the solvent in which the molecules of life are dissolved and the availability of water therefore a critical factor that affects the growth of cells. ${ }^{6}$ Water is the most common surface-exposed compound which covers $70 \%$ of the earth, but only $2.6 \%$ is available as potential drinking water. ${ }^{7}$ Water is a colourless, tasteless and odourless liquid. Taste and odour can originate from natural inorganic and organic chemical contaminants and biological sources or processes (e.g., aquatic microorganisms), from contamination by synthetic chemicals, from corrosion or as a result of water treatment (e.g., chlorination). Taste and odour may also develop during storage and distribution due to microbial activity. Taste and odour in drinking-water may be indicative of some form of pollution or of a malfunction during water treatment or distribution. It may therefore be an indication of the presence of potentially harmful substances. The cause should be investigated and the appropriate health authorities should be consulted, particularly if there is a sudden or substantial change. Colour, cloudiness, particulate matter, and visible organisms may also be noticed by consumers and may create concerns about the quality and acceptability of a drinkingwater supply. Water can be used for various purposes; these include domestic uses such as cooking, laundry, bathing etc. it is also used for industrial purposes for example in the production of chemicals and pharmaceutical products, food, and irrigation which is normally 
useful during dry season when there is less availability of water and also for recreational purposes. Water is said to be contaminated when harmful microbial or chemical agents are present in it though it may have seemingly pleasant taste, odour and appearance. Polluted water is one with unacceptable appearance, taste, and odour resulting from the introduction of domestic, industrial, or agricultural waste causing an alteration in its composition or conditions so that it becomes less suitable for any or all of its purposes for which it would be suitable in its natural state. Pollution may be in form of solid, liquid or gas and its sources may be physical, chemical, or biological. However, biological pollutants are the most important as far as individual and public health is concerned. ${ }^{8}$

According to the World Health Organization (WHO), drinking water should be free from any organism that might pose a health risk to the human population. ${ }^{9}$ Water authorities throughout the world are thus dedicated to ensure that the water that reaches the consumer is safe for consumption and free from any substances that may be harmful to health. Water is normally disinfected before being distributed to the different end-point users and the microbial levels of the water, when leaving the treatment plant, have to be within limits set by water authorities. By the time it reaches the tap in the house of the consumer, water quality may differ dramatically from the quality at the time of treatment. The decline in microbial water quality may be attributed to the recovery and subsequent growth of sub-lethally damaged bacteria, to system deficiencies such as cross connections, broken water mains and contamination during bulk storage and repairs, ${ }^{10}$ and to the presence of biofilms within the distribution system from which cells may be released into the flow. ${ }^{11}$ Drinking water distribution systems provide an oligotrophic environment, and post-treatment recovery and growth of bacteria is therefore a concern because of the effect the environment can have on public health. ${ }^{12,13}$ This current study therefore, focused on the determination of the resistant pattern of bacteria isolated from treated and untreated water samples, to determine the physicochemical parameters and bacteriological quality of treated and untreated water distributed in some parts of Ilorin and to determine the microbial load on water samples in Ilorin with a view to highlight that though chlorine is a bactericide, it does not destroy all bacteria unless it is given under suitable conditions and that bacteria exhibit a high level of resistance to antibiotics.

\section{Materials and methods}

\section{Study area}

The study area is Ilorin, Kwara state capital, North central region of Nigeria.

\section{Sampling procedures}

All samples were collected in sterile sample bottles as follows:

Tap water: The tap was cleaned by wiping with a clean cloth to remove any dirt. It was then turned on at maximum flow and water was allowed to run for 1-2 minutes. The tap was turned off and sterilized for about one minute with the flame from a cigarette lighter. The tap was then carefully turned on and water allowed to flow for 1-2 minutes at a medium flow rate. The sample bottle was carefully opened and immediately held under the water jet and filled. This was done holding the protective cap of the bottle face down to prevent any entry of dust, which may contaminate the samples were immediately taken back to the laboratory for analysis

Stream water: The sample bottles were held by the lower part and submerged to a depth of about $20 \mathrm{~cm}$, with the mouth facing against the flow of water current and the bottles stoppered.

Well water: Sterilized buckets were used to fetch water from the well. The sample bottles were held by the lower part to the bucket and submerged to the bucket and the bottles stoppered.

Borehole water: The same process as (i) above three samples were collected from each sampling sites.

\section{Sample collection and inoculation}

\section{2 sampling sites were analysed and designated as:}

a. Site A - Unilorin dam (Untreated)

b. Site B - Well water, Tanke (Untreated)

c. Site C-Tap water, Tanke (Treated)

d. Site D - Unilorin conference centre (Treated)

e. Site E - Unity bridge stream (Untreated)

f. Site F - Unilorin boys hostel (Treated)

g. Site $\mathrm{G}-$ Well water, pipe line (Untreated)

h. Site H - Tap water, Fate (Treated)

i. Site I - Borehole water, Unilorin primary school (Untreated)

j. Site J - Tap water, coca cola road (Treated)

k. Site $\mathrm{k}-$ Tap water, T and L pharmaceutical (Treated)

1. Site L - Microbiology laboratory Unilorin (Treated)

Three samples were collected from each sampling site. The inoculation was done by using spread plate method, i.e. $0.1 \mathrm{ml}$ of sample was taken and dispensed in sterile Petri dish containing sterile molten agar (i.e. Nutrient Agar, MacConkey Agar and Eosin Methylene Blue). The plates were incubated upside down at $37^{\circ} \mathrm{C}$ for 24hours. After incubation, isolates were sub- cultured for pure culture which were then stored on agar slants.

\section{Physicochemical analysis of samples \\ Turbidity}

Turbidity of the sample was determined using Thermo Scientific Spectrophotometer (Genesys 20) at $490 \mathrm{~nm}$. This was done by firstly setting blank, followed by the sample in cuvette tube. This was also done for all the samples at each analysis. The unit is NTU (Nephelometric Turbidity Unit).

\section{$\mathrm{pH}$ determination}

$\mathrm{pH}$ of the sample was determined using a digital electrode $\mathrm{pH}$ meter (Clida Instrument PHS-25C Precision). The electrode meter was standardised prior to use using buffer solutions of $\mathrm{pH} \mathrm{4,7}$ and 9 before every measurement. This was done by dipping the electrode of the $\mathrm{pH}$ meter into the water sample and then the reading at the $\mathrm{pH}$ screen was recorded. This $\mathrm{pH}$ was done for all the samples at each analysis.

\section{Temperature determination}

The temperature of each sample was measured with the use of a mercury bulb thermometer. The thermometer was cleaned with distilled water and immersed into the samples. 


\section{Free residual chlorine}

The free chlorine residual was determined with the aid of the Lovibond comparator using its chlorine standard discs. The orthotilidine indicator was used and distilled water served as the control.

\section{Determination of chloride ion}

The method of $\mathrm{AOAC}^{14}$ was used for the determination of chloride ion by titration of the water sample with silver nitrate. To $100 \mathrm{ml}$ of the water sample was added with potassium chromate $(5 \%, 1 \mathrm{ml})$ and titrated with $0.1 \mathrm{M}$ silver nitrate solution, the first appearance of buff colour, marks the end point of the titration.

\section{Calculation}

$$
\text { Chloride }(m g / L)=\frac{V_{T} \times M \times 100,000}{m l . o f \text { sample }}
$$

Where $\mathrm{V}_{\mathrm{T}}=$ titre value

$\mathrm{M}=$ mole of $\mathrm{AgNO}_{3}$

\section{Determination of sulphate by gravimetric method}

$50 \mathrm{ml}$ of the water sample was carefully measured into a beaker to which 2 drops of methyl red indicator was added which turn the solution into light yellow later add 2 drops of concentrated $\mathrm{HCl}$ was added later in excess which turn to pink and the solution was then boil to reduce to $1 / 3$, hot barium chloride solution prepared was added to it with stirring until the formation of white precipitate is complete, two drops of barium chloride solution was added in excess and allow the precipitate to settle down which was then filtered by using a what man filter paper No. 1 and the precipitate was then washed several time with distilled water until it was free of chloride ions. The filter papers along with the precipitate were transferred carefully into crucible and ignite at $100^{\circ} \mathrm{C}$ in ovens, then cooled in desiccators and finally weighed. Sample 1,2 and 3 turns faint yellow on heating but pink on addition of methyl orange and concentrated $\mathrm{HCl}$ and on heating turns to faint yellow but sample 4 remains pink and sample 5 also remain faint pink in colour.

\section{Calculation}

$233.4 \mathrm{~g}$ of $\mathrm{BaSO}_{4}$ contains $96.06 \mathrm{~g}$ of $\mathrm{SO}_{4}^{2-}$

$$
\mathrm{W}_{\mathrm{g}} \text { of } \mathrm{BaSO}_{4} \text { contain } \mathrm{X}_{\mathrm{g}} \text { of } \mathrm{SO}_{4}^{2-}
$$

$$
X_{g}=\frac{W_{g} \text { of } 96.06}{233.4 .}=y(g) \text { of } \mathrm{SO}_{4}^{2-} \text { in } 50 \mathrm{ml}
$$

\section{Determination of nitrate in water sample}

This was determined by colorimetric method. ${ }^{14}$ To a $10 \mathrm{ml}$ of the water sample, $10 \mathrm{ml}$ sulphuric acid $(13 \mathrm{~N})$ was added in a conical flask. The flask was then placed in a water bath at $10^{\circ} \mathrm{C}$ for about 3 minutes after which brucine reagent $(0.5 \mathrm{ml})$ was added. The tube was then place in a water bath for 25 minutes the colour changes to yellow. It is then allowed to cool and the absorbance of the sample was read using a spectrophotometer machine. The absorbance was read at $481 \mathrm{~nm}$.

\section{Total hardness of water}

The method of Ademoroti ${ }^{15}$ was used for the determination of total hardness of water. $25 \mathrm{ml}$ of the water sample was carefully measured and make it up to $50 \mathrm{ml}$ with distilled water in a standard flask. Then $1 \mathrm{ml}$ of buffer solution, 3 drops of indicator (Eriochrome black T) and masking reagent $(0.25 \mathrm{~g} \mathrm{KCN})$ were added into the measured sample and titrated against $0.01 \mathrm{M}$ EDTA. The water sample when the reagents were all added to it turns faint pink. This was titrated to light green at the end point of the titration.

\section{Calculation}

Hardness $(E D T A)$ as $m g / \mathrm{LCaCO}_{3}=\frac{V \times A 1000}{m l . o f \text { sample }}$

Where $\mathrm{V}=\mathrm{ml}$ titration for sample

$\mathrm{A}=\mathrm{mg} \mathrm{CaCO}_{3}$ equivalent to $1 \mathrm{ml}$ EDTA titration

\section{Microbiological analysis of samples}

\section{The water samples were examined for:}

a. Total bacterial counts

b. Total enteric bacterial count

c. Total coliform counts using the multiple tubes or most probable number technique

Total bacterial counts: This was carried out according to the standard methods for examination of water and waste water. ${ }^{16} 0.1 \mathrm{ml}$ of sample was taken and dispensed in sterile Petri dish containing sterile molten agar (i.e. Nutrient Agar and Eosin Methylene Blue). The plates were incubated upside down at $37^{\circ} \mathrm{C}$ for 24 hours. After incubation, the total bacterial counts were then recorded as number of bacteria per $\mathrm{ml}$ of each water samples.

Total enteric bacterial count: Using a sterile pipette, $1 \mathrm{ml}$ of the sample was pipetted into a test-tube containing $9 \mathrm{ml}$ of sterile distilled water. The dilution was continued until the seventh dilution was attained for untreated water and the third dilution for treated water. Sterile and cool molten macConkey agar was poured asceptically into the petridishes. Sterile pipettes were used to pipette $0.1 \mathrm{ml}$ of the sample into labelled petridishes. A sterile spreader was used to spread the samples on the plate. The plates were then incubated in an incubator for 24 hours at $37^{\circ} \mathrm{C}$. After 24 hours of incubation, the plates were examined and number of colonies of the plates were counted and recorded as cfu/ml. Duplicate plates were prepared for each of the samples. Average count was recorded.

Total coliform counts: This was carried out using the multiple tube test fermentation technique. This technique is made up of three tests which are; the presumptive, the confirmed and the completed tests. The 5:5:5 tube test as discussed by ${ }^{17,18}$ was used. The qualitative coliform test was carried out according to the method of Fawole \& Oso ${ }^{19}$ as follows:

Presumptive test: This was done by inoculating sterile lactose broth containing inverted Durham's tube in a test tube with the water sample. Incubation was done at $37^{\circ} \mathrm{C}$ for $24-48$ hours. Acid and gas production was taken as a positive presumptive test for coliform.

Confirmed test: This was carried out by streaking the surface of a sterile MacConkey agar with the loopful of the tube with a positive presumptive test above. Incubation was done at $37^{\circ} \mathrm{C}$ for 24 hours. A colony with pinkish or reddish colour was taken as a confirmed test for a typical coliform. 
Completed test: This was carried out by inoculating sterile MacConkey broth containing inverted Durham's tube with loopful of a typical colony from the confirmed test. Incubation was done at $37^{\circ} \mathrm{C}$ for $24-48$ hours. Presence of acid and gas formation showed a completed test for coliforms.

\section{Characterization of isolates}

The bacterial isolates on the plates were characterized based on some parameters such as the shape of the colony, edge, pigmentation, elevation, colony surface, consistency, a size and optics characteristics of different colonies observed. Various biochemical tests were carried out for further identification of the isolates and also, various staining techniques as described by Fawole \& Oso. ${ }^{19}$

\section{Statistical analysis}

The data obtained was subjected to statistics using mean and standard error of mean. Analysis of variance (ANOVA) test under Completely Randomized Design (CRD) was done. Post-Hoc test using Duncan Multiple Range Test (DMRT) was used to test for the means that are significant differently from the other, which are presented by alphabet in superscripts in the tables presented.

\section{Results}

\section{Physicochemical parameters of samples}

The physicochemical parameters of the water samples are presented in Table 1-3. The temperature of the samples ranged from 20.3 to $25.7^{\circ} \mathrm{C}$. The lowest $\mathrm{pH}$ of 5.7 was recorded for untreated well water while the highest $\mathrm{pH}$ of 7.4 was recorded for untreated Unilorin dam water. The $\mathrm{pH}$ values of all the water samples were acidic except the $\mathrm{pH}$ value of untreated Unilorin dam water which was slightly alkaline. The highest turbidity values were obtained for untreated Unilorin dam water and untreated Unity bridge stream water, while the lowest turbidity value was obtained for treated Unilorin conference centre water, treated tap water at coca cola road, and treated Unilorin Microbiology Laboratory water. Table 2 shows the residual chlorine of the treated water samples. The lowest value of $0.1 \mathrm{mg} / 1$ was obtained for treated Unilorin Unilorin conference centre water and treated tap water from $\mathrm{T}$ and $\mathrm{L}$ Pharmaceutical, while the highest value of $0.9 \mathrm{mg} / 1$ was obtained for treated tap water from Tanke. Table 3 shows the different levels of chloride ion, hardness, sulphate ion and nitrate in the water samples. Table 3 revealed that all samples showed a range of hardness of water from $4.37 \mathrm{mg} / 1$ to $11.20 \mathrm{mg} / \mathrm{l}$. The result of analysis of the hardness in water shows that there was no significant difference $(\mathrm{p}<0.05)$ among sample $\mathrm{F}$ and $\mathrm{L}$, sample D, J, K and also sample A and I. But there was a significant difference among E, H, C, G and B.

Table 3 also revealed that in the sulphate ion there was significant difference ( $\mathrm{p}>0.05$ ) among $\mathrm{B}, \mathrm{C}, \mathrm{E}, \mathrm{G}$ and $\mathrm{H}$ with $\mathrm{B}$ having the highest sulphate ion level of $5.14 \mathrm{mg} / \mathrm{l}$. The result of analysis of sulphate ion in water also shows that there was no significant difference $(p<0.05)$ among samples D, F, J, K, L and samples A and I with D having the lowest level of sulphate ion of $0.87 \mathrm{mg} / \mathrm{l}$. Furthermore, Table 4 revealed that the result of analysis of Nitrate in water shows that there was no significant difference $(\mathrm{p}<0.05)$ among samples $\mathrm{F}$ and $\mathrm{L}$, $\mathrm{J}$ and $\mathrm{K}, \mathrm{E}$ and I, A, B, C, D and H. However, an exception was noted for G where the lowest Nitrate value of $1.04 \mathrm{mg} / 1$ was recorded.

\section{Microbiological analysis of water samples}

Table 5 revealed that sample E recorded the highest bacteria count $\left(6.6 \times 10^{9} \mathrm{cfu} / \mathrm{ml}\right)$. The lowest count of $0.5 \times 10^{4} \mathrm{cfu} / \mathrm{ml}$ was seen in sample F. Total enteric bacteria count as shown in Table 5 revealed that the samples had counts ranged between $0.3 \times 10^{4} \mathrm{cfu} /$ $\mathrm{ml}$ and $2.1 \times 10^{9} \mathrm{cfu} / \mathrm{ml}$. However, sample G had the highest enteric bacteria count $\left(2.1 \times 10^{9} \mathrm{cfu} / \mathrm{ml}\right)$ of the analysis. Table 5 also shows the result of total coliform count using Most Probable Number (MPN) method for all samples. It revealed that there were no faecal coliform contaminations in samples D, F, I and L. They have same total coliform count of $0 \mathrm{cfu} / 100 \mathrm{ml}$. The highest count was observed in samples $\mathrm{B}$ and $\mathrm{E}$ of the analysis $\left(1.8 \times 10^{3} / 100 \mathrm{ml}\right)$.

Table I Physicochemical properties of samples

\begin{tabular}{llll}
\hline Sample & Temperature & $\mathbf{p H}$ & Turbidity \\
\hline A & $21.0 \pm 0.03^{\mathrm{a}}$ & $7.4 \pm 1.00^{\mathrm{e}}$ & $0.82 \pm 0.07^{\mathrm{c}}$ \\
B & $23.7 \pm 0.0 \mathrm{I}^{\mathrm{b}}$ & $6.8 \pm 0.08^{\mathrm{d}}$ & $0.57 \pm 0.02^{\mathrm{b}}$ \\
C & $20.3 \pm 0.03^{\mathrm{a}}$ & $6.8 \pm 0.08^{\mathrm{d}}$ & $0.27 \pm 0.08^{\mathrm{a}}$ \\
D & $23.3 \pm 0.0 \mathrm{I}^{\mathrm{b}}$ & $6.3 \pm 0.03^{\mathrm{c}}$ & $0.25 \pm 0.08^{\mathrm{a}}$ \\
E & $20.7 \pm 0.03^{\mathrm{a}}$ & $6.1 \pm 0.02^{\mathrm{b}}$ & $0.85 \pm 0.07^{\mathrm{c}}$ \\
F & $23.3 \pm 0.0 \mathrm{I}^{\mathrm{b}}$ & $6.8 \pm 0.08^{\mathrm{d}}$ & $0.26 \pm 0.08^{\mathrm{a}}$ \\
$\mathrm{G}$ & $20.3 \pm 0.03^{\mathrm{a}}$ & $5.7 \pm 1.00^{\mathrm{a}}$ & $0.58 \pm 0.02^{\mathrm{b}}$ \\
$\mathrm{H}$ & $23.3 \pm 0.0 \mathrm{I}^{\mathrm{b}}$ & $6.0 \pm 0.02^{\mathrm{b}}$ & $0.27 \pm 0.08^{\mathrm{a}}$ \\
I & $20.3 \pm 0.0 \mathrm{I}^{\mathrm{b}}$ & $6.4 \pm 0.03^{\mathrm{c}}$ & $0.49 \pm 0.02^{\mathrm{b}}$ \\
J & $24.3 \pm 0.0 \mathrm{I}^{\mathrm{b}}$ & $6.0 \pm 0.02^{\mathrm{b}}$ & $0.25 \pm 0.08^{\mathrm{a}}$ \\
K & $25.7 \pm 0.04^{\mathrm{c}}$ & $6.1 \pm 0.02^{\mathrm{b}}$ & $0.27 \pm 0.08^{\mathrm{a}}$ \\
L & $23.3 \pm 0.0 \mathrm{I}^{\mathrm{b}}$ & $6.3 \pm 0.03^{\mathrm{c}}$ & $0.25 \pm 0.08^{\mathrm{a}}$ \\
\hline
\end{tabular}

Values are Mean \pm Standard Error of Mean (SEM). Means in the same column not sharing a common subscript are significantly different at $\mathrm{P}<0.05$ while means sharing the same letters are not significantly different.

A, unilorin dam (Untreated); B, well water tank (untreated); C, tap water tank (treated); D, unilorin conference centre (treated); $\mathrm{E}$, unity bridge stream (untreated); F, unilorin boys hostel (treated); G, well water pipe line (untreated); $\mathrm{H}$, tap water fate (treated); I, borehole water unilorin primary school (untreated); J, tap water coca cola road (treated); $\mathrm{K}$, tap water $\mathrm{T}$ and $\mathrm{L}$ pharmaceutical (treated); L, microbiology laboratory unilorin (treated)

Table 2 Residual chlorine of treated water samples

\begin{tabular}{ll}
\hline Samples & Residual chlorine $(\mathrm{Mg} / \mathrm{L})$ \\
\hline C & $0.9 \pm 0.02^{\mathrm{c}}$ \\
D & $0.1 \pm 0.05^{\mathrm{a}}$ \\
F & $0.6 \pm 0.05^{\mathrm{a}}$ \\
H & $1.1 \pm 0.02^{\mathrm{c}}$ \\
$\mathrm{J}$ & $0.5 \pm 0.08^{\mathrm{b}}$ \\
K & $0.1 \pm 0.08^{\mathrm{b}}$ \\
\hline
\end{tabular}

Values are Mean \pm Standard Error of Mean (SEM). Means in the same column not sharing a common subscript are significantly different at $\mathrm{P}<0.05$ while means sharing the same letters are not significantly different.

A, unilorin dam (Untreated); B, well water Tank (untreated); C, tap water tank (treated); D, unilorin conference centre (treated); E, unity bridge stream (untreated); F, unilorin boys hostel (treated); G, well water pipe line (untreated); $\mathrm{H}$, tap water fate (treated); I, borehole water unilorin primary school (untreated); J, tap water coca cola road (treated); $\mathrm{K}$, tap water $\mathrm{T}$ and $\mathrm{L}$ pharmaceutical (treated); L, microbiology laboratory unilorin (treated) 
Table 3 Different levels of chloride ion, hardness, sulphate ion and nitrate in the water samples

\begin{tabular}{|c|c|c|c|c|}
\hline Samples & $\begin{array}{l}\text { Chloride } \\
\text { ion } \\
\text { (Mg/L) }\end{array}$ & $\begin{array}{l}\text { Hardness } \\
\text { (Mg/L) }\end{array}$ & $\begin{array}{l}\text { Sulphate } \\
\text { ion }(\mathrm{Mg} / \mathrm{L})\end{array}$ & $\begin{array}{l}\text { Nitrate } \\
\text { (Mg/L) }\end{array}$ \\
\hline A & $3.92 \pm 0.05^{\mathrm{e}}$ & $4.60 \pm 0.0 \mathrm{I}^{\mathrm{d}}$ & $1.43 \pm 0.09 c$ & $1.40 \pm 0.04^{\circ}$ \\
\hline B & $10.40 \pm 1.00^{i}$ & $12.11 \pm 1.00^{\circ}$ & $5.14 \pm 1.00^{\mathrm{h}}$ & $1.43 \pm 0.04$ \\
\hline C & $6.55 \pm 1.00^{\mathrm{h}}$ & $10.20 \pm 1.00^{\circ}$ & $4.54 \pm 1.00^{f}$ & $1.42 \pm 0.04$ \\
\hline D & $2.70 \pm 0.0 \mathrm{I}^{\mathrm{a}}$ & $4.50 \pm 0.05^{b}$ & $0.87 \pm 0.0 \mathrm{I}^{\mathrm{a}}$ & $1.40 \pm 0.04$ \\
\hline$E$ & $4.81 \pm 1.00^{g}$ & $9.04 \pm 1.00^{\mathrm{e}}$ & $2.62 \pm 1.00^{d}$ & $1.34 \pm 0.01^{\circ}$ \\
\hline$F$ & $3.20 \pm 1.00^{c}$ & $4.40 \pm 0.0 \mathrm{I}^{\mathrm{a}}$ & $0.92 \pm 0.01 \mathrm{a}^{\mathrm{b}}$ & $1.10 \pm 1.00^{b}$ \\
\hline G & $11.20 \pm 1.00^{\circ}$ & $11.20 \pm 1.00^{\mathrm{h}}$ & $5.08 \pm 1.00 \mathrm{~g}$ & $1.04 \pm 1.00^{\circ}$ \\
\hline $\mathrm{H}$ & $4.40 \pm 1.00^{f}$ & $9.91 \pm 1.00^{f}$ & $3.93 \pm .100^{\mathrm{e}}$ & $1.42 \pm 0.04$ \\
\hline I & $3.91 \pm 0.05^{\mathrm{e}}$ & $4.6 \mathrm{I} \pm 0.0 \mathrm{I}^{\mathrm{d}}$ & $1.43 \pm 0.09 c$ & $\mathrm{I} .30 \pm 0.0 \mathrm{I}$ \\
\hline J & $3.30 \pm 1.00^{\mathrm{d}}$ & $4.55 \pm 0.0 I^{c}$ & $0.9 \mathrm{I} \pm 0.0 \mathrm{l} \mathrm{a}^{\mathrm{b}}$ & $1.20 \pm 0.0^{c}$ \\
\hline K & $2.73 \pm 0.0 \mathrm{I}^{\mathrm{a}}$ & $4.52 \pm 0.05 b^{c}$ & $0.96 \pm 0.09^{b}$ & $1.21 \pm 0.08$ \\
\hline L & $2.90 \pm 1.00^{\mathrm{b}}$ & $4.37 \pm 0.0 \mathrm{I}^{\mathrm{a}}$ & $0.88 \pm 0.0 \mathrm{I}^{\mathrm{a}}$ & $1.10 \pm 1.00^{b}$ \\
\hline
\end{tabular}

Values are Mean \pm Standard Error of Mean (SEM). Means in the same column not sharing a common subscript are significantly different at $\mathrm{P}<0.05$ while means sharing the same letters are not significantly different.

A, unilorin dam (Untreated); B, well water Tank (untreated); C, tap water tank (treated); D, unilorin conference centre (treated); E, unity bridge stream (untreated); F, unilorin boys hostel (treated); G, well water pipe line (untreated); $\mathrm{H}$, tap water Fate (treated); I, borehole water unilorin primary school (untreated); J, tap water coca cola road (treated); $\mathrm{K}$, tap water $\mathrm{T}$ and $\mathrm{L}$ pharmaceutical (treated); L, microbiology laboratory unilorin (treated)

Table 4 Percentage frequency of occurrence of bacteria in water samples
Table 6 shows the occurrence of bacteria isolated from the various samples and how they were evenly distributed in the samples. Bacillus subtilis, Pseudomonas aeruginosa and Staphylococcus aureus were the most isolated among all the samples with $75 \%$ followed by Escherichia coli which had 58.3\%, Enterobacter aerogenes had 33.3\% and Klebsiella pneumonia and Streptococcus faecalis had 25\%. The percentage frequency of occurrence of bacterial isolates is presented in Table 6. For tap water from Tanke (designated C), Pseudomonas aeruginosa had greater percentage frequency of occurrence than Staphylococcus aureus. For the bore hole water (designated I), Staphylococcus aureus had the highest percentage frequency of occurrence. In all the samples that Pseudomonas aeruginosa occurred, it had a higher percentage frequency of occurrence than any other bacterial isolate present except for tap water at coca cola road (designated J) and bore hole water at Unilorin Primary School (designated I).

\section{Susceptibility patterns of isolates to antibiotics}

Result showed from Table 7 that all organisms isolated, were resistant, intermediate or susceptible to all the antibiotics. Escherichia coli was shown to be resistant to erythromycin, Pseudomonas aeroginosa showed resistance to teracyclin, chloramphenicol, amoxycillin and nitrofurantoin. Staphylococcus aureus shows resistance to erythromycin, chloramphenicol, nalidixic acid and cotrimozazole. Also, Klebsiella pneumoniae shows resistance to chloramphenicol, gentamycin and amoxycillin. Streptococus faecalis was only resistant to erythromycin. Entrobacter aerogenes was resistant to chloramphenicol and nalidixic acid. Bacillus subtilis was only resistant to erythromycin. All the microorganisms isolated were susceptible to ofloxacin and augmentin.

\begin{tabular}{|c|c|c|c|c|c|c|c|c|c|c|c|c|}
\hline \multirow{3}{*}{ Isolates } & \multicolumn{12}{|c|}{ Water sources } \\
\hline & \multicolumn{7}{|l|}{ Tap } & \multicolumn{2}{|c|}{ Well } & \multicolumn{2}{|c|}{ Stream } & \multirow{2}{*}{$\begin{array}{l}\text { Borehole } \\
\text { I }\end{array}$} \\
\hline & C & D & $\mathbf{F}$ & $\mathbf{H}$ & J & $\mathbf{K}$ & $\mathbf{L}$ & B & G & A & $\mathbf{E}$ & \\
\hline Escherichia coli & - & 15 & - & 5 & 5 & - & - & 10 & 10 & 10 & 15 & - \\
\hline Staphylococcus aureus & 25 & - & - & 45 & - & 25 & 75 & 30 & 25 & 25 & 25 & 50 \\
\hline Pseudomonas aeruginosa & 75 & 85 & 75 & - & 40 & 50 & - & 55 & - & 35 & 30 & 25 \\
\hline Bacillus subtilis & - & - & 25 & 45 & 50 & 25 & 25 & & 35 & 20 & - & 25 \\
\hline Enterobacter aerogenes & - & - & - & 5 & 5 & - & - & - & 10 & - & 10 & - \\
\hline Klebsiella pneumonia & - & - & - & - & - & - & - & - & 5 & 10 & 10 & - \\
\hline Streptococcus faecalis & - & - & - & - & - & - & - & 5 & 15 & - & 10 & - \\
\hline Total & 100 & 100 & 100 & 100 & 100 & 100 & 100 & 100 & 100 & 100 & 100 & 100 \\
\hline
\end{tabular}

Present $=+$; Absent $=$ -

Table 5 Total bacterial count, total enteric bacterial count and total coliform count (MPN) of water samples

\begin{tabular}{llll}
\hline Samples & Total bacteria count cfu/ml & Total enteric cfu/ml & Total coli form count $(\mathbf{m p n}) \mathrm{cfu} / 100 \mathrm{ml}$ \\
\hline A & $2.3 * 10^{9}$ & $1.1 * 10^{9}$ & $9.2 * 10^{2}$ \\
B & $2.2 * 10^{9}$ & $1.8 * 10^{9}$ & $1.8 * 10^{4}$ \\
C & $1.4 * 10^{5}$ & $0.9 * 10^{4}$ & $5.4 * 10^{2}$ \\
D & $1.5 * 10^{5}$ & $0.5 * 10^{4}$ & 0 \\
E & $6.6 * 10^{9}$ & $2.0^{*} 10^{9}$ & $1.8 * 10^{4}$ \\
F & $0.5 * 10^{4}$ & $0.5 * 10^{4}$ & 0 \\
G & $3.6 * 10^{9}$ & $2.1 * 10^{9}$ & $3.5 * 10^{2}$ \\
\hline
\end{tabular}


Table Continued..

\begin{tabular}{llll}
\hline Samples & Total bacteria count cfu/ml & Total enteric cfu/ml & Total coli form count $(\mathbf{m p n}) \mathrm{cfu} / 100 \mathrm{ml}$ \\
\hline $\mathrm{H}$ & $1.8 * 10^{5}$ & $1.3 * 10^{4}$ & $0.9 * 10^{1}$ \\
$\mathrm{I}$ & $2.2 * 10^{8}$ & $1.4 * 10^{7}$ & 0 \\
$\mathrm{~J}$ & $2.2 * 10^{5}$ & $0.4 * 10^{4}$ & $0.7 * 10^{2}$ \\
$\mathrm{~K}$ & $2.1 * 10^{5}$ & $0.8 * 10^{4}$ & $5.4 * 10^{2}$ \\
$\mathrm{~L}$ & $0.6 * 10^{4}$ & $0.3 * 10^{4}$ & 0
\end{tabular}

Values are Mean \pm Standard Error of Mean (SEM). Means in the same column not sharing a common subscript are significantly different at $\mathrm{P}<0.05$ while means sharing the same letters are not significantly different.

A, unilorin dam (Untreated); B, well water tank ( untreated), C, tap water tank (treated); D, unilorin conference centre (treated); E, unity bridge stream (untreated); F, unilorin boys hostel (treated); G, well water pipe line (untreated); H, tap water fate (treated); I, borehole water unilorin primary school (untreated); J, tap water coca cola road (treated); K, tap water T and L pharmaceutical (treated); L: microbiology laboratory unilorin (treated)

Table 6 Occurrence of bacteria in water samples

\begin{tabular}{|c|c|c|c|c|c|c|c|c|c|c|c|c|}
\hline \multirow{3}{*}{ Isolates } & \multicolumn{12}{|c|}{ Water sources } \\
\hline & \multicolumn{7}{|l|}{ Tap } & \multirow{2}{*}{$\begin{array}{l}\text { Well } \\
\text { B }\end{array}$} & \multicolumn{2}{|c|}{ Stream } & \multicolumn{2}{|c|}{ Borehole } \\
\hline & C & D & $\mathbf{F}$ & $\mathbf{H}$ & J & $\mathbf{K}$ & $\mathbf{L}$ & & G & $\mathbf{A}$ & $\mathbf{E}$ & $\mathbf{I}$ \\
\hline Escherichia coli & - & + & - & + & + & - & - & + & + & + & + & - \\
\hline Staphylococcus aureus & + & - & - & + & - & + & + & + & + & + & + & + \\
\hline Pseudomonas aeruginosa & + & + & + & - & + & + & - & + & - & + & + & + \\
\hline Bacillus subtilis & - & - & + & + & + & + & + & + & + & + & - & + \\
\hline Enterobacter aerogenes & - & - & - & + & + & - & - & - & + & - & + & - \\
\hline Klebsiella pneumonia & - & - & - & - & - & - & - & - & + & + & + & - \\
\hline Streptococcus faecalis & - & - & - & - & - & - & - & + & + & - & + & - \\
\hline
\end{tabular}

Present $=+$; Absent $=$ -

Table 7 Antibiotics zone of Inhibition measurement from organisms isolated

\begin{tabular}{|c|c|c|c|c|c|c|c|}
\hline Antibiotics & E. coli & P.aeruginosa & $\begin{array}{l}\text { S. } \\
\text { aureus }\end{array}$ & S. faecalis & K. pneumonia & E. aerogenes & B.subtilis \\
\hline Erythromycin (E) & $13^{R}$ & $17^{1}$ & $5^{\mathrm{R}}$ & $8^{R}$ & $15^{\mathrm{s}}$ & $18^{\mathrm{s}}$ & $10^{R}$ \\
\hline Tetracycline (TE) & $16^{1}$ & $9^{R}$ & $14^{\prime}$ & $14^{1}$ & $14^{\prime}$ & $19^{5}$ & $19^{5}$ \\
\hline Amoxycilin (AMX) & $22^{s}$ & $12^{R}$ & $19^{s}$ & $21^{s}$ & $I I^{R}$ & $22^{\mathrm{s}}$ & $19^{5}$ \\
\hline Chloramphenicol (C) & $21^{\mathrm{s}}$ & $8^{\mathrm{R}}$ & $9^{R}$ & $20^{\mathrm{s}}$ & $9^{R}$ & $7^{\mathrm{R}}$ & $21^{s}$ \\
\hline Cotrimoxazole (COT) & $20^{s}$ & $16^{1}$ & $5^{\mathrm{R}}$ & $19^{5}$ & $22^{\mathrm{s}}$ & $20^{\mathrm{s}}$ & $18^{\mathrm{s}}$ \\
\hline Nalidixicacid (NAL) & $|9|$ & $20^{s}$ & $I I^{R}$ & $16^{1}$ & $13^{1}$ & $I I^{R}$ & $16^{5}$ \\
\hline Gentamycin (G) & $21^{s}$ & $18^{1}$ & $18^{\mathrm{s}}$ & $19^{\mathrm{s}}$ & $I I^{R}$ & $15^{1}$ & $18^{\mathrm{s}}$ \\
\hline Ofloxacin (OFL) & $26^{S}$ & $18^{s}$ & $27^{s}$ & $25^{s}$ & $19^{5}$ & $26^{5}$ & $28^{\mathrm{s}}$ \\
\hline Nitrofuratoin (NIT) & $|7|$ & $5^{\mathrm{R}}$ & $22^{\mathrm{s}}$ & $19^{5}$ & $20^{\mathrm{s}}$ & $21^{\mathrm{s}}$ & $18^{\mathrm{s}}$ \\
\hline Augumetin (AUG) & $19^{5}$ & $22^{\mathrm{s}}$ & $21^{s}$ & $19^{5}$ & $21^{s}$ & $23^{\mathrm{s}}$ & $22^{\mathrm{s}}$ \\
\hline
\end{tabular}

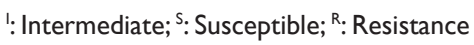

\section{Discussion}

The results of the physicochemical analysis of the samples that were collected showed that the $\mathrm{pH}$ range was between $\mathrm{pH}$ which is measure of hydrogen ion concentration is an indicator of acidity or alkalinity of water. As presented in Table 1, all samples showed a $\mathrm{pH}$ that acidic to neutral (5.7-7.4). This result is in consonance with the work of Kolawole et al. ${ }^{20}$ The $\mathrm{pH}$ value within a bacterial cell is believed to be approximately neutral and bacterial is known to grow well within $\mathrm{pH}$ values ranging from 6.0 and 9.0. ${ }^{21}$ The $\mathrm{pH}$ value of water is controlled by the amount of dissolved $\mathrm{CO}_{2}$, Carbonates, and bicarbonates. It is governed by the type of contaminated bases, degree of ionization, extent of hydrolysis and buffering action. George ${ }^{22}$ stated that water or raw water with $\mathrm{pH}$ between 5 and 9 does serves as a good source of raw water to be treated for supply. According to $\mathrm{WHO},{ }^{23}$ no Health-Based Guideline value for turbidity has been proposed. However, the appearance of water with a turbidity of less than 5 NTU is usually acceptable to consumers, although this may vary with local circumstances. For this research work, a turbidity range of 0.25 and $0.82 \mathrm{NTU}$ was observed (Table 1). As observed from the result, the high faecal coliform contamination observed in some of the sample may be due to the high turbidity observed. This 
is in line with the findings of Hall-Stoodley et al. ${ }^{24}$ who showed that turbidity can bear an indirect relationship to the health aspect of water quality.

All samples show a temperature range between $20.3^{\circ} \mathrm{C}$ and $24.3^{\circ} \mathrm{C}$. The effectiveness of the use chlorine and other disinfectant is controlled by temperature. According to Hall-Stoodley et al. ${ }^{24}$ the temperature of an environment should be controlled for the effectiveness of the antimicrobial agent. The temperature observed favours the growth of microorganisms and this is in agreement with WHO guideline for drinking water quality. ${ }^{25}$ According to Fransolet et al. ${ }^{26}$ most bacteria isolated from water were mesophiles and that temperature influences the growth and cell yield of bacteria. Water may be clear in appearance, free from odour and taste and yet not be suitable for drinking. The sanitary quality of water should therefore be subjected to bacteriological procedure. Coliform is usually used as an indicator of water quality and has remained the cornerstone of drinking water regulations. Free chlorine residual ranged from non-detectable quantities of $0.1 \mathrm{mg} / 1$ to a little over $1.1 \mathrm{mg} / 1$ (Table 2). It was observed that most of the samples collected had very little quantities of disinfectant residual that fell short of the recommended $0.5 \mathrm{mg} / 1$ or higher. ${ }^{9}$

Disinfection ensures that pathogenic organisms are destroyed, bacterial regrowth is suppressed, and risk of microbial contamination avoided. A decrease in disinfectant residual to an ineffective level paves way for deterioration of the bacteriological quality of treated water. The efficacy of a disinfectant depends on a combination of factors that include the type, amount, or concentration applied, contact time, type of organisms present and the physical and chemical characteristics of the water. ${ }^{16}$ The chloride levels of the water samples were also analysed. Chloride levels in the water ranged from $2.70 \mathrm{mg} / \mathrm{l}$ to $11.20 \mathrm{mg} / \mathrm{l}$. $\mathrm{WHO}^{25}$ specifications permits up to a maximum level of $250 \mathrm{mg} / 1$ of chloride in drinking water. At higher levels, water could become salty in taste and could enhance corrosion rates of iron, steel and other plumbing materials. Presently, conventional water treatment processes do not remove chlorides and if the chloride content of water has to be reduced, some form of desalination has to be applied. ${ }^{27}$

Nitrate was another inorganic constituent that was monitored in the water samples. Nitrate levels ranged from $1.04 \mathrm{mg} / 1$ to $1.43 \mathrm{mg} / \mathrm{l}$. However, all values recorded fall within acceptable limits of $50 \mathrm{mg} / 1$ specified by $\mathrm{WHO}^{25}$ standards. Contamination of drinking of drinking water supply could occur at leaking points in the distribution network where nitrites from nitrogenous fertilizer can gain access to drinking water supplies. Similarly, when nitrite is detected in potable water in considerable amounts, it is indication of sewage/bacterial contamination and inadequate disinfection. Nitrates can be removed through anion exchange. Sulphate concentrations were within the WHO permissible limits of $200 \mathrm{mg} / \mathrm{L}$. The sulphate levels ranged from $0.87 \mathrm{mg} / 1$ to $5.14 \mathrm{mg} / 1$. Sulphate have no health implication on human but at high concentration, sulphate could cause gastro intestinal irritation. ${ }^{28}$ Sulphate concentration is a function of the volume of river water especially during rainy season. The values of the total hardness of water ranged from $4.37 \mathrm{mg} / 1$ to $12.11 \mathrm{mg} / 1$. $\mathrm{Ca}^{2+}$ and $\mathrm{Mg}^{2+}$ are responsible for water hardness. Their concentrations are within the WHO minimum permissible limits of 300 and $500 \mathrm{mg} / \mathrm{L}$ respectively.

Table 6 revealed sample $(\mathrm{G})$ having the highest bacteria count throughout the period of analysis. This may be due to the absence of chemicals and disinfectant in the sample. Since the actions of these chemicals and disinfections is known to reduce bacteria load in drinking water. This is in agreement with the work of Costerton et al. ${ }^{29}$
The high bacteria count in samples without chlorine over the period of analysis especially Escherichia coli is in agreement with the findings of September et al. ${ }^{30}$ who also proposed that the identity of putative pathogenic isolate revealed that high number of organisms including Enterobacter and Klebsiella were present. Total enteric bacteria count as shown in Table 6 revealed that the samples had counts ranged between $0.3 \times 10^{4} \mathrm{cfu} / \mathrm{ml}$ and $2.1 \times 10^{9} \mathrm{cfu} / \mathrm{ml}$. However, sample $\mathrm{G}$ had the highest enteric bacteria count $\left(2.1 \times 10^{9} \mathrm{cfu} / \mathrm{ml}\right)$ of the analysis.

The prevalence of members of the family Enterobacteriaceae is due to the contamination of the site with faecal materials. The prevalence of these organisms near the stream bank than the centre is probably due to the high degree of direct and indirect human contact and his activities in the immediate environment of the stream. Also found around the stream was cow dung due to animal herding around the stream. The result of total coliform count; Most Probable number (MPN) presented in Table 6 showed no faecal contamination observed in sample D, F, I and L is in disagreement with a similar work carried out by September et al..$^{30}$ and that of Consterton et al. ${ }^{29}$ who showed high faecal contaminations in sample without chlorine. The result obtained from sample A, B, E and G however complies with their various findings. The result obtained from Most Probable number show that sample ( $\mathrm{B}$ and $\mathrm{E}$ ) had the highest number of microorganisms $\left(1.8 \times 10^{4} \mathrm{cfu} / 100 \mathrm{ml}\right)$. This agrees with the work of Thomas et al. ${ }^{31}$ who proposed that Escherichia coli number tend to increase with water residence time in distribution networks when not treated.

Through the early part of the twentieth century, there appeared to be a general feeling that the same battery of observations and tests could be used to characterize and identify any kind of bacterium. But as different, "exotic" types of bacteria were discovered, it was found that they would tend not to grow in the standard test media or even in the usual conditions of incubation. Obligate parasites and strict anaerobes were among the emerging groups of bacteria needing special methods for growth and characterization. ${ }^{32}$ A total number of seven bacteria species were isolated: Staphylococcus aureus, Escherichia coli, Streptococcus faecalis, Klebsiella pneumoniae. Pseudomonas aeroginosa, Enterobacter aerogenes and Bacillus subtilis. Ideally, drinking water should not contain any microorganisms known to be pathogenic to man. The presence of the, Escherichia coli, Streptococcus faecalis and Klebsiella pneumoniae conforms to the work of September et al..$^{30}$ who also reported similar result. Staphylococcus aureus is a Gram positive, forms cluster, nonmotile, non-spore forming and a facultative anaerobe. This bacterium is test positive for Coagulase, Catalase and forms yellow colonises on agar. It is mostly found on the nasal passage and axillae. The bacterium causes food poison, toxic shock syndrome, skin lesion etc. It can also cause bacteraemia, pneumonia and/or osteomyelitis. They get into water by a number of ways which includes poor hygiene and sanitary conditions. ${ }^{33}$ Streptococcus faecalis is heterogeneous group of Gram positive bacteria. In this group, the organism Streptococcus faecalis is now considered an opportunistic infection i.e. it is contacted from one's normal micro flora. However, disease usually occurs in individual with predisposing factors such as viral infection of the respiratory tract, physical injury to the fat, alcohol or diabetes. ${ }^{33}$ Transmission of infection through water source is rarely the route of transmission of this organism.

Bacillus sp are mostly of great medical importance. Their importance as pathogens is enhanced by their ability to form endospore. Their presence in water constitutes serious effect to human health. Their ability to form spores in response to an unfavourable condition explains their better chances to survive in water than the 
coliform group of bacteria. Some Klebsiella pneumonia has been reported to have a persistent adherence to iron pipes due to some of its properties, hence decreases the disinfection potential of chlorine in treated water, increasing the corrosion rates of pipes. Escherichia coli, a Gram-negative, rod-shaped bacterium is commonly found in the lower intestine of warm-blooded organisms (endotherms). E. coli cells are a major component of feces, and fecal-oral transmission is the major route through which pathogenic strains of the bacterium cause disease. Cells are able to survive outside the body for a limited amount of time, which makes them ideal indicator organisms to test environmental samples for fecal contamination. ${ }^{34,35}$

The water samples analysed showed high percentage of Pseudomonas aeroginosa. The bacterium is able to directly affect the bacteriological water quality and in fact on several animal and plant pathogens. For instance, Pseudomonas spp. Invades and burn areas and cause urinary tract infection. ${ }^{33}$ Infections with Pseudomonas spp. is unfortunately difficult to treat as they are resistant to many antibiotics. So their presence in water is highly significant and in fact $\mathrm{WHO}^{36}$ refers to them as "nuisance organisms" and can be controlled relatively easily by the usual water treatment process. Bacillus subtilis, Pseudomonas aeruginosa and Staphylococcus aureus was the most isolated among all the samples with $75 \%$ followed by Escherichia coli which had $58.3 \%$, Enterobacter aerogenes had 33.3\% and Klebsiella pneumonia and Streptococcus faecalis had 25\% (Table 6). The percentage frequency of occurrence of bacterial isolates is presented in Table 5. For tap water from Tanke (designated C), Pseudomonas aeruginosa had greater percentage frequency of occurrence than Staphylococcus aureus. For the bore hole water (designated I), Staphylococcus aureus had the highest percentage frequency of occurrence. In all the samples that Pseudomonas aeruginosa occurred, it had a higher percentage frequency of occurrence than any other bacterial isolate present except for tap water at coca cola road (designated J) and bore hole water at Unilorin Primary School (designated I).

The wide distribution of coli forms and other microorganisms in all water samples is shown in the results of this study, with Pseudomonas aeruginosa, Staphylococcus aureus and E. Coli occupying an interesting position. The recovery of $E$. coli in almost all the samples except the bore-hole (I) and four (D, F, K and L) other treated water samples indicates recent contamination and risk of exposure of other bacterial pathogens. Also presence of Bacillus subtilis in raw water samples (A, B, G and $\mathrm{H}$ ) indicates the level of pollution of the raw water samples. From Table 4, it is seen that coliform organisms were almost present in all the water samples. E. coli can cause different diseases of economic importance for example, diarrhoea, and gastrointestinal disorder.

Table 7 showed that all organisms isolated, were resistant, intermediate or susceptible to all the antibiotics. Escherichia coli was shown to be resistant to erythromycin, Pseudomonas aeruginosa showed resistance to teracyclin, chloramphenicol, amoxycillin and nitrofurantoin. Staphylococcus aureus shows resistance to erythromycin, chloramphenicol, nalidixic acid and cotrimozazole. Also, Klebsiella pneumoniae shows resistance to chloramphenicol, gentamycin and amoxycillin. Entrobacter aerogenes was resistant to chloramphenicol and nalidixic acid. Streptococus faecalis and Bacillus subtilis was only resistant to erythromycin. All the microorganisms isolated were susceptible to ofloxacin and augmentin. The antibiotic sensitivity tests showed that ofloxacin and augumentin proved most effective against the bacterial isolates. The prevalence of antibiotics resistant bacteria isolates is of greater importance .Some isolates exhibit multiple resistances while others showed single resistance pattern.

Along the years, many bacteria have proven to be resistant to antimicrobial agents. The reason for this resistance may be due to single step mutation of chromosomal origins such as a change in single amino acids as in sulphonamides or change in enzyme as in Rifampin. The substantial degree of antibiotic resistance shown by strains suggests the presence of transmissible drug resistance plasmids among the strains. ${ }^{37}$ Microorganisms can develop resistance to antimicrobial agents by destroying or inactivating the drug, prevention of access to target cells or by altering the means of entry of the drug. My study on antibiotic resistance isolates corroborate with the findings of Olayemi ${ }^{37}$ which shows the resistance pattern of coliform obtained from two sources to different antibiotics. This study also confirmed the efficacies of free chlorine as water disinfectant. Chlorine was shown to inactivate some organisms mostly coli forms (D, F, K, and L). Chlorination is still the most widely used method of disinfecting water. The effectiveness of disinfection is commonly determined by monitoring coliform bacteria. However the absence of culturable bacteria may not adequately reflect the state of population given the present ever increasing population and greater environment contamination, the risk of contamination of public water supply increases. As a result of this, water quality and supply continuity deteriorate making water supply less effective on reducing diseases.

\section{Conclusion and recommendation}

Good water supplies are a pre-requisite for public health and well being. In the absence of safe drinking water supplies, diseases such as diarrhea, dysentery, and skin and eye infestation are more common. Given that, in many developing countries, the main risk posed by contaminated water supplies is that of water borne diseases, test may be reduced to a series of critical parameters or indicators of hygiene risk. The choice of antibiotics for the control of these bacteria strains can be less complicated if the situation in the distribution system is constantly monitored. ${ }^{37}$ The major objective of any water quality control program is to maintain the portability achieved and measured at treatment all the way through the distribution system to the ultimate consumer. The results obtained from this study revealed that the water in the stream and well (A, B, E and G) is not portable for drinking as it contains pathogenic organisms capable of causing serious outbreak of water borne diseases. Since all samples showed a $\mathrm{pH}$ of (5.7-7.4) the water can be treated and become safe for consumption because George $^{22}$ stated that water or raw water with $\mathrm{pH}$ between 5 and 9 can serve as a good source of raw water to be treated for supply. The number of bacteria that survive in treated water depends on their susceptibility which is influenced by changes in environmental and physiochemical factors. Also, improper conditions of a disinfectant can actually enhance bacterial growth conditions. Antibiotics resistance has been identified as a serious public health problem. Diseases such as typhoid, urinary tract infections, etc have become hard to treat with antibiotic due to the resistance of microorganisms to antibiotics. Therefore, it is recommended that guideline values for drinking water should be strictly adhered to by institutions, individuals, and treatment plants. Examination of drinking water should be both frequent and regular and the bacteriological examination should comply with the suggestions given in the drinking water guidelines.

\section{Acknowledgements}

None. 


\section{Conflict of interest}

The author declares no conflict of interest.

\section{References}

1. Adams AR, Moss MO. Food Microbiology. 3rd ed. Royal society of Chemistry. UK: Thomas Graham House, Science Park, Milton Road, Cambridge; 1999. p. 1-478.

2. Harrison P. Water, everywhere and not a drop to drink. In the Third Revolution-Population, Environment and Sustainable World. USA: New York, Penguin Books Limited; 1994. 50 p.

3. Brock TD, Madigan MT, Martinko JM, et al. Significance of Water. Biology of Microorganisms. 7th ed. USA: New Jersey, Prentice-hall inc. Eaglewood Cliffs; 1994.

4. Bonde GJ. Importance of non-faecal coliforms and Germ counts as water quality criteria for potable water. 1978. p. 1-6.

5. Behnke JJ, Haskell ER. Ground water Nitrate distribution beneath fresno. USA: California, $A W W A ; 1968 ; 60(4): 477-480$.

6. Olayemi AB, Eniola KIT, Kolawole OM. Bacteriology Today with Laboratory Manual. University of Ilorin Press; 2007. 39 p.

7. Szewzyk U, Szewzyk R, Manz W, et al. Microbiological safety of drinking water. Аппи Rev Microbiol. 2000;54:81-127.

8. Hofkes EH, Huisman L, Sundaresan BB, et al. Quality of water sources; small community water supplies. UK: Britain Calliards ND Great Yar mounth; 1981. p. 53-54.

9. World Health Organization. Guidelines for Drinking Water Quality, Volume 1, Recommendations. Switzerland: WHO, Geneva; 2004. p. 1-515.

10. Craun GF, Calderon RL. Water disease outbreaks caused by distribution systems deficiencies. J Am Wat Wks Assoc. 2001;93(9):64-75.

11. Camper A, Burr M, Ellis B, et al. Development and sructure of drinking water biofilms and techniques for their study. J Appl Microbiol. 1998;85(1):S1-S12.

12. Assanta MA, Roy D, Montpetit D. Adhesion of Aeromonas hydrophila to water distribution system pipes after different contact times. $J$ Food Prot. 1998;61(10):1321-1329.

13. Kerr CJ, Osborn KS, Robson GD, et al. The relationship between pipe material and biofilm formation in a laboratory model system. $J$ Appl Microbiol. 1999;85(1):S29-S38.

14. Anonymous. Official Methods of Analysis of AOAC international. 17th ed. USA: Maryland; 2002.

15. Ademoroti CMO. Standard methods for water and effluents analysis. Nigeria: Foludex Press Ltd. 1996;3:29-118.

16. Standard Methods for the Examination of Water. 23rd ed. USA: New York, American Publication Health Association; 1995.

17. Salle AJ. Bacteriology of Water in Fundamental Principle of Bacteriology. 7th ed. USA: New York, Mc Graw Hill; 1973. p. 687-710.

18. Nnochiri E. Medical Microbiology in the tropics. UK: London, Oxford University Press, Ely House; 1975. 386 p.
19. Fawole MO, Oso BA. Laboratory Manual of Microbiology. 4th ed. Nigeria: Ibadan, Spectrum Books Limited; 2004. p. 16-80.

20. Kolawole OM, Ajayi KT, Olayemi AB, et al. Assessment of water quality in asa river (nigeria) and its indigenous clarias gariepinus fish. Int $J$ Environ Res Public Health. 2011;8(11):4332-4352.

21. Harry WG, Jacob IB. Effect of pH value. Water Resources and Pollution control. UK: Litton Educational Publishing Inc; 1976. p. 146-147.

22. George S. Basic water treatment for application worldwide. UK: London, Thomas Telford Ltd; 1979. $224 \mathrm{p}$.

23. Guidelines for drinking water quality. geneva: incorporating $1^{\text {st }}$ and $2^{\text {nd }}$ addenda, Recommendations. 3rd ed. World Health Organization, Switzerland: Geneva; 2008:213-220.

24. Hall-Stoodley L, Costerton JW, Stoodley P. Bacterial biofilms: from the natural environment to infectious diseases. Nat Rev Microbiol. 2004;2(2):95-108.

25. Guidelines for Drinking Water Quality. 2nd ed. Volume 1, Recommendations. World Health Organization, Switzerland: Addendum, Geneva; 1993:1-31.

26. Fransolet G, Willers G, Massechelein WJ. Influence of temperature on bacteria. Modelling, analysis and design of water distribution systems. American Water Works Association, Denve, Colorado development in waters. USA: Ozone Sciencel; 1985:205-227.

27. Twort AC, Ratnayaka DD, Brandt MJ. Significant Chemicals and Physiochemical Parameters in Water. Water Supply. 5th ed. London: Arnold and Iwa publishing; 2000. p. 197-221.

28. International Standard for Drinking Water. 3rd ed. Switzerland: WHO, Geneva; 1971.70 p.

29. Costerton JW, Lewandowski Z, Caldwell DE, et al. Microbial biofilms. Ann Rev Microbiol. 1995;49:711-745.

30. September SM, Brözel VS, Venter SN. Diversity of non-tuberculoid Mycobacterium in biofilms of urban and semi-urban drinking water distribution systems. Appl Environ Microbiol. 2004;70(12):7571-7573.

31. Thomas C, Gibson H, Hill DJ, et al. Campylobacter epidemiology: an aquatic perspective. $J$ Appl Microbiol. 1998;85(1):168S-177S.

32. Lindquist S. Protein folding sculpting evolutionary change. Cold Spring Harb Symp Quant Biol. 2009;74:103-108.

33. Prescott LM, Harley JP, Klein DN. Marine and fresh water environments. In: Microbiolology. 4th ed. USA: New York, Mc Graw-Hill, Companies Inc; 1999. $685 \mathrm{p}$.

34. Feng $\mathrm{P}$, Weagant $\mathrm{S}$, Grant M. $\mathrm{BAM}_{4}$ : Enumeration of Escherichia coli and the Coliform Bacteria. Bacteriological Analytical Manual. 8th ed. WHO, USA: FDA/Center for Food Safety \& Applied Nutrition; 2002.

35. Thompson A. "E. coli Thrives in Beach Sands". Live Science. 2007.

36. Guidelines for drinking-water quality. 2nd ed. Switzerland: Geneva, Surveillance and control of community supplies; $1984.237 \mathrm{p}$.

37. Olayemi AB. Microbial potability of bottled and packaged drinking water hawked in Ilorin metropolis. International journal of Environmental Health Research. 1999;9(3):245-248. 